\title{
DEVELOPMENT OF MOUSE EMBRYOS WITH ABNORMALITIES INDUCED BY PARENTAL HEAT STRESS
}

\author{
A. R. BELLVE* * \\ Ruakura Research Centre, Private Bag, Hamilton, New Zealand
}

(Received 30th August 1972)

\begin{abstract}
Summary. Albino ICR mice were used in a factorial experiment to study abnormal embryonic development that was induced by a $24-\mathrm{hr}$ exposure of parent mice to an ambient temperature of $34.5^{\circ} \mathrm{C}$ and $65 \%$ relative humidity. Two-cell embryos recovered from eighty females killed at $48 \mathrm{hr}$ were cultured in vitro to the stage reached $120 \mathrm{hr}$ after HCG. The pattern of embryonic development in vivo was determined by observing embryos recovered from 240 females killed at $64,72,88$ or $96 \mathrm{hr}$ after HCG.

Exposure of females caused an accumulation of two-, three- and fourcell embryos $(P<0.01)$ following development in vivo or in vitro. Complete developmental arrest at the two-cell stage accounted for the major portion of embryonic mortality. In some partially affected two-cell embryos, one blastomere was able to undergo a limited number of divisions, asynchronous cleavage, to form three- or five-cell trophoblastic vesicles, or false blastocysts. Following exposure of males, developmental retardation and/or arrest at the morula stage accounted for a major portion of the embryonic death that had occurred by Day 10 of gestation. Significant male $\times$ female treatment interactions in the data on number of morulae, blastocysts and viable fetuses indicated that embryonic mortality due to male and female stress may be operating through similar mechanisms.
\end{abstract}

\section{INTRODUCTION}

The phenomenon of embryonic mortality can result from a wide variety of natural causes, but it is difficult to study because of its low incidence in most populations. Exposure of parent animals to high ambient temperatures is known to induce embryonic death in domestic animals under field conditions. In mice, high environmental temperatures cause a marked increase in preimplantation embryonic death (Pennycuik, 1967; Elliott, 1968). Following exposure of females, this occurs primarily as a result of retardation and/or arrest in embryonic development during early cleavage divisions (Bellvé, 1972). By contrast, similar treatment of the male, mediating the effect through

* Present address: Harvard Medical School, Laboratory of Human Reproduction and Reproductive Biology, 45 Shattuck Street, Boston, Massachusetts 02115, U.S.A. 
the spermatozoa, induces embryonic death at some later stage in development (Burfening, Elliott, Eisen \& Ulberg, 1970; Bellvé, 1972).

Studying these phenomena at a single period in time provides only limited information on the stage in the developmental process when the morphological abnormalities become apparent. The current experiments involved sequential observations during development of mouse embryos in vivo. The resulting data were compared with the pattern of embryonic failure which occurred during concurrent culture in vitro.

\section{MATERIALS AND METHODS}

\section{Experimental design}

The 380 female and 99 male ICR albino mice (Institute of Cancer Research, Philadelphia, Pennsylvania) of proven fertility were housed in an environmental control chamber maintained at $21 \pm 2^{\circ} \mathrm{C}$ during the experimental period. Treatment consisted of exposing designated animals to an environmental temperature of $34.5 \pm 0.2^{\circ} \mathrm{C}$ and $65 \pm 5 \%$ relative humidity for $24 \mathrm{hr}$. Males stressed on Day 1 and control males were each placed with a single nonparous 6- to 10- week-old female at 17.00 hours on Day 3. The males were kept with females from Days 3 to 8 inclusive, each female being replaced daily.

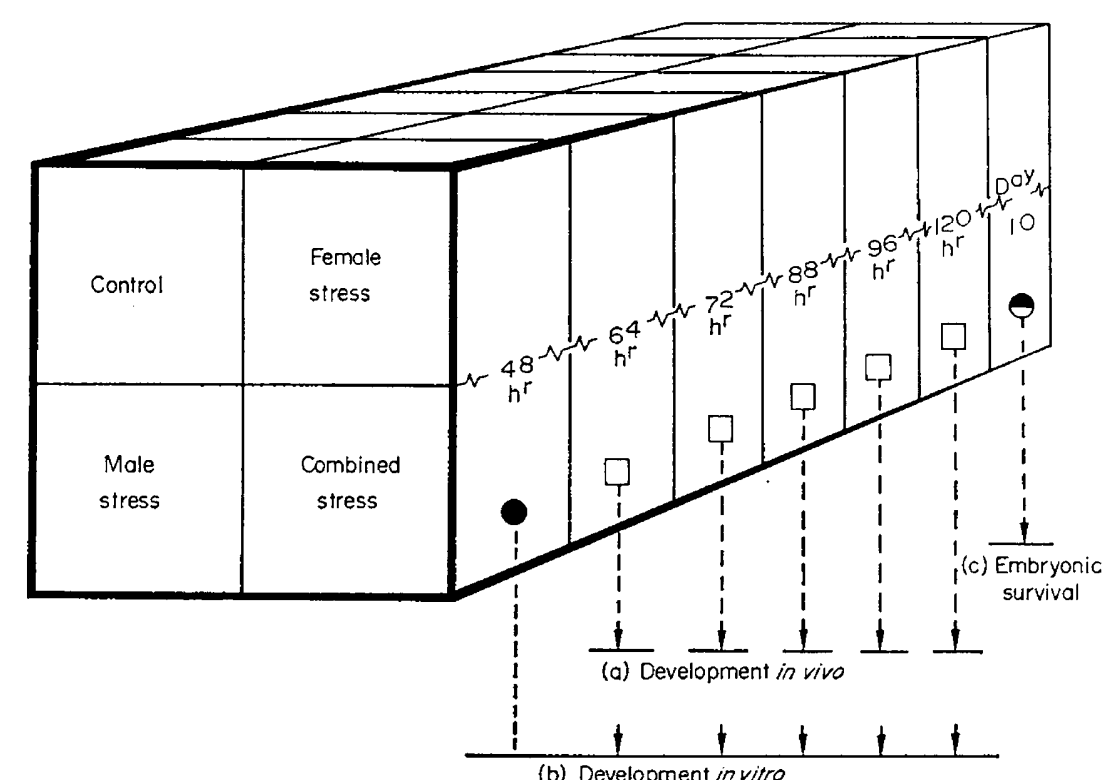

TExT-FIG. 1. Schematic presentation of the basic factorial experiment for studying treatment effects on embryonic development in vivo and in vitro. The design consisted of twenty female mice allocated at random to ten control females (five mated to control males and five to stressed males) and ten stressed females (five mated to control males and five to stressed males). The pattern of embryonic development in vivo (a) was studied by replicating this basic design three times for each of the periods 64, 72, 88 and $96 \mathrm{hr}$ after HCG. This was compared with development in vitro (b) of embryos recovered from females in four replicates and killed $48 \mathrm{hr}$ after $\mathbf{H C G}$. Females (c), in three replicates, were killed at Day 10 of gestation to assess treatment effects on embryonic survival. 
Males failing to mate with at least two females within this period were discarded and subsequently replaced.

Females were induced to superovulate with an intraperitoneal injection of 4 to 6 i.u. PMSG between 16.00 and 17.00 hours, followed $48 \mathrm{hr}$ later by 4 to 6 i.u. HCG. At this time $(0 \mathrm{hr})$, females were randomly allocated to be mated either to a control or to a stressed male. The presence of a copulatory plug the following morning was used to determine whether mating had occurred. Mated females were then allotted to a control or a stress treatment, and treatment commenced at 16.00 hours ( $24 \mathrm{hr}$ after HCG) on the day a plug was detected. Rectal temperatures were recorded on all animals before and after the treatment period using procedures outlined previously (Bellvé, 1972).

The experiment was composed of three sections: (a) development in vivo, (b) development in vitro, and (c) embryonic survival at Day 10 of gestation (Text-fig. 1). Each section, carried out concurrently, consisted of a factorial experiment in which twenty females were randomly designated to be one of a group of ten control females or a group of ten stressed females. Within each group, five females were randomly allocated to be mated to control males, and five to stressed males, to give the treatment groups: control, female stress, male stress, and combined stress (Text-fig. 1).

\section{Procedure for embryonic development in vivo}

This section of the experiment was carried out in three replicates. Sixty females were killed at each of the periods 64, 72, 88 and $96 \mathrm{hr}$ after HCG (Text-fig. 1). Embryos were recovered from individual females by flushing excised oviducts with culture medium (BMOG-2; Brinster, 1969) containing $0.005 \%$ eosin y $(\mathrm{w} / \mathrm{v})$ and then classified by the developmental stages: one-cell, two-cell, three-cell, four-cell (four to six blastomeres), eight-cell (seven to twelve blastomeres), morula (thirteen or more blastomeres but no blastocoelic cavity) and blastocyst (blastocoelic cavity present).

The number of embryos in each cell stage with one or more blastomeres that had incorporated eosin y were recorded. Eosin y (Gurr Ltd) is a vital dye that is selectively incorporated by non-viable cells (Holmberg, 1961).

\section{Procedure for embryonic development in vitro}

This experimental section was replicated four times, using a total of eighty females. Late two-cell embryos, recovered from individual females killed $48 \mathrm{hr}$ after $\mathbf{H C G}$, were placed in $0.2 \mathrm{ml}$ culture medium containing $0.001 \%$ eosin y $(\mathrm{w} / \mathrm{v})$ under light paraffin oil in $60-\mathrm{mm}$ Petri dishes. The incubator was maintained at $37.5^{\circ} \mathrm{C}$ and gassed with $5 \% \mathrm{CO}_{2}$ in air. The embryos were reexamined at 64, 72, 88, 96 and $120 \mathrm{hr}$ after HCG. The numbers of embryos in each cell stage and embryos with blastomeres incorporating eosin y were recorded.

\section{Embryonic survival at Day 10 of gestation}

A total of sixty females, comprising three replicates, were killed at Day 10 of gestation in order to assess pre- and post-implantation mortality. The numbers of implant sites, viable fetuses and non-viable embryos were recorded (Bellvé, 1972). 


\section{Statistical procedure}

The data were analysed by a modified general least squares procedure (Harvey, 1960). Data on male and female rectal temperatures were analysed to determine the influence of groups, male and female treatment, and interactions. The six groups of mice were defined as: (1) development in vitro, (2) periods of 64, (3) 72, (4) 88 and (5) $96 \mathrm{hr}$ of development in vitro, and (6) Day 10 of gestation. The data for development in vivo and in vitro were analysed within two-, three-, four- and eight-cell, and morula and blastocyst stages. Appropriate periods were deleted from the analyses when the required cell stage was absent. The in-vivo data were analysed over periods and treatments, but to avoid bias from correlated errors, analyses on the in-vitro data were confined to within periods. A comparison of embryonic development in vivo and in vitro was made within periods $64,72,88$ and $96 \mathrm{hr}$ to assess possible effects due to culture and culture $\times$ treatment interactions.

Adjustment by covariance techniques was used where linear or linear and quadratic terms for total ova recovered were significant. When certain mean squares were clearly non-significant, they were pooled with the appropriate error term. Differences between treatment groups within cell stages were assessed on adjusted means by Duncan's multiple range test (Duncan, 1955).

\section{RESULTS}

\section{Rectal temperature}

The mean rectal temperatures of both males and females were increased $(P<0.01)$ by approximately $2^{\circ} \mathrm{C}$ after exposure to the elevated environmental temperature. Analyses of variance on male and female rectal temperature indicated that both male and female treatment effects were significant $(P<0 \cdot 01)$. In both instances, differences between groups were not evident.

\section{Embryonic development in vivo}

The mean number of embryos within cell stages for each period and treatment combination are given in Table 1 and Text-figs 2 and 3 . The analyses (Bellvé, 1970) indicated significant $(P<0.01)$ effects due to female treatment in the data on the number of two-, three- and eight-cell, and morula and blastocyst stages. It can be seen from Text-fig. 2 that female treatment resulted in a marked increase $(P<0.01)$ in the number of two-, three- and four-cell embryos in both the female stress and combined stress groups. In consequence, the number of embryos able to develop through the eight-cell and morula stages to become blastocysts was significantly $(P<0.01)$ reduced (Table 1$)$. The absence of significant $(P>0.05)$ differences between periods indicated that the major portion of the two- and three-cell embryos was completely arrested rather than retarded in development.

Significant period $\times$ female treatment interactions are evident in the data on four-cell $(P<0.05)$, eight-cell $(P<0.01)$, morula $(P<0.05)$ and blastocyst $(P<0.05)$ stages. The interaction at the four-cell stage is due to there being fewer embryos present at $64 \mathrm{hr}$ in the female stress and combined stress groups compared to the control and male stress groups, but more embryos present at 
Table 1. Distribution of cell stages during development of mouse embryos in vivo

\begin{tabular}{|c|c|c|c|c|c|c|}
\hline \multirow[b]{2}{*}{$\begin{array}{c}\text { Hours after } \\
\qquad H C G\end{array}$} & \multirow[b]{2}{*}{$\begin{array}{l}\text { Cell } \\
\text { stage }\end{array}$} & \multicolumn{4}{|c|}{ Treatment groups } & \multirow[b]{2}{*}{ $\pm S . E$. } \\
\hline & & Control & $\begin{array}{c}\text { Female } \\
\text { stress }\end{array}$ & $\begin{array}{l}\text { Male } \\
\text { stress }\end{array}$ & $\begin{array}{l}\text { Combined } \\
\text { stress }\end{array}$ & \\
\hline 64 & $\begin{array}{l}\text { 2-cell } \\
\text { 3-cell } \\
\text { 4-cell* } \\
\text { 8-cell† }\end{array}$ & $\begin{array}{r}1 \cdot 63^{\mathrm{a}} \\
0 \cdot 16^{\mathrm{a}} \\
16 \cdot 23^{\mathrm{a}} \\
11 \cdot 26^{\mathrm{a}}\end{array}$ & $\begin{array}{r}17.02^{\mathrm{b}} \\
2.57^{\mathrm{b}} \\
7.89^{\mathrm{b}} \\
1.07^{\mathrm{b}}\end{array}$ & $\begin{array}{r}3 \cdot 26^{\mathrm{a}} \\
0 \cdot 45^{\mathrm{a}} \\
16 \cdot 40^{\mathrm{a}} \\
9 \cdot 44^{\mathrm{a}}\end{array}$ & $\begin{array}{r}19 \cdot 35^{b} \\
3 \cdot 36^{b} \\
7 \cdot 82^{b} \\
0.73^{b}\end{array}$ & $\begin{array}{l}1 \cdot 86 \\
0.50 \\
1.57 \\
1 \cdot 75\end{array}$ \\
\hline 72 & $\begin{array}{l}\text { 2-cell } \\
3 \text {-cell } \\
\text { 4-cell* } \\
8 \text {-cell } †\end{array}$ & $\begin{array}{r}0 \cdot 80^{\mathrm{a}} \\
0 \cdot 00^{\mathrm{a}} \\
7 \cdot 27^{\mathrm{a}} \\
23 \cdot 25^{\mathrm{a}}\end{array}$ & $\begin{array}{c}11 \cdot 68^{\mathrm{b}} \\
3.98^{\mathrm{b}} \\
9 \cdot 11^{\mathrm{ab}} \\
6.41^{\mathrm{b}}\end{array}$ & $\begin{array}{r}3 \cdot 62^{\mathrm{a}} \\
1 \cdot 14^{\mathrm{a}} \\
4 \cdot 25^{\mathrm{c}} \\
20 \cdot 35^{\mathrm{a}}\end{array}$ & $\begin{array}{c}9 \cdot 21^{\mathrm{b}} \\
2 \cdot 41^{\mathrm{b}} \\
6 \cdot 19^{\mathrm{bc}} \\
10 \cdot 91^{\mathrm{b}}\end{array}$ & $\begin{array}{l}1.86 \\
0.50 \\
1.57 \\
1.75\end{array}$ \\
\hline 88 & $\begin{array}{c}\text { 2-cell } \\
\text { 3-cell } \\
\text { 4-cell* } \\
\text { 8-cell } \dagger \\
\text { Morula } \\
\text { Blastocyst }\end{array}$ & $\begin{array}{c}0 \cdot 76^{\mathrm{a}} \\
0 \cdot 07^{\mathrm{a}} \\
0 \cdot 28^{\mathrm{a}} \\
0 \cdot 20^{\mathrm{a}} \\
14 \cdot 01^{\mathrm{a}} \\
15 \cdot 07\end{array}$ & $\begin{array}{c}10 \cdot 31^{\mathrm{b}} \\
2 \cdot 19^{\mathrm{b}} \\
4 \cdot 00^{\mathrm{a}} \\
1 \cdot 45^{\mathrm{a}} \\
10 \cdot 45^{\mathrm{ab}} \\
2 \cdot 84^{\mathrm{a}}\end{array}$ & $\begin{array}{c}0 \cdot 00^{\mathrm{a}} \\
0 \cdot 00^{\mathrm{a}} \\
0 \cdot 00^{\mathrm{a}} \\
0 \cdot 48^{\mathrm{a}} \\
22 \cdot 12 \\
6 \cdot 69^{\mathrm{a}}\end{array}$ & $\begin{array}{c}11 \cdot 08^{\mathrm{b}} \\
2 \cdot 78^{\mathrm{b}} \\
1 \cdot 89^{\mathrm{a}} \\
4 \cdot 02^{\mathrm{a}} \\
6 \cdot 76^{\mathrm{b}} \\
2 \cdot 84^{\mathrm{a}}\end{array}$ & $\begin{array}{l}1 \cdot 86 \\
0.50 \\
1.57 \\
1 \cdot 75 \\
1.55 \\
1.78\end{array}$ \\
\hline 96 & $\begin{array}{c}\text { 2-cell } \\
\text { 3-cell } \\
\text { 4-cell* } \\
\text { 8-cell } † \\
\text { Morula } \\
\text { Blastocyst }\end{array}$ & $\begin{array}{r}1 \cdot 14^{\mathrm{a}} \\
0 \cdot 14^{\mathrm{a}} \\
0 \cdot 78^{\mathrm{a}} \\
0 \cdot 35^{\mathrm{a}} \\
7 \cdot 40^{\mathrm{a}} \\
20 \cdot 73^{\mathrm{a}}\end{array}$ & $\begin{array}{r}12 \cdot 33^{\mathrm{b}} \\
2 \cdot 36^{\mathrm{b}} \\
4 \cdot 85^{\mathrm{a}} \\
1 \cdot 80^{\mathrm{a}} \\
4 \cdot 07^{\mathrm{b}} \\
5 \cdot 51^{\mathrm{b}}\end{array}$ & $\begin{array}{r}0 \cdot 27^{\mathrm{a}} \\
0 \cdot 11^{\mathrm{a}} \\
0 \cdot 00^{\mathrm{a}} \\
0 \cdot 92^{\mathrm{a}} \\
9 \cdot 85^{\mathrm{a}} \\
17 \cdot 74^{\mathrm{a}}\end{array}$ & $\begin{array}{c}12 \cdot 25^{\mathrm{b}} \\
2 \cdot 68^{\mathrm{b}} \\
1 \cdot 89^{\mathrm{a}} \\
3 \cdot 83^{\mathrm{a}} \\
5 \cdot 60^{\mathrm{ab}} \\
4 \cdot 72^{\mathrm{b}}\end{array}$ & $\begin{array}{l}1.86 \\
0.50 \\
1.57 \\
1.75 \\
1.55 \\
1.78\end{array}$ \\
\hline
\end{tabular}

Values expressed are mean number/fermale \pm S.E. The least squares means were calculated following adjustment by covariance techniques for total number of embryos recovered.

* Four to six blastomeres.

† Seven to twelve blastomeres.

a,b Means within periods and cell stages not denoted with the same superscript are significantly different $(P<0.05)$ as determined by Duncan's multiple range test.

later periods (Text-fig. 2). At the eight-cell, morula and blastocyst stages, the period $\times$ female treatment interactions are, in each case, indicative of female treatment differences being more marked in some periods after HCG than in others (Text-figs 2 and 3 ).

The only effect that could be ascribed to male treatment was a significant $(P<0.05)$ reduction in the number of embryos that developed to the blastocyst stage. Differences between treatment means indicated that the effect was primarily restricted to the 88 -hr period where fewer blastocysts were recovered from females of the male stress group (Table 1). This appeared to be due to an accumulation $(P<0.05)$ of embryos at the morula stage (Text-fig. 3$)$.

The combination of stressed males and females resulted in significant male $x$ female treatment interactions at the morula $(P<0.01)$ and blastocyst $(P<0.05)$ stages, indicating that the two treatments were not operating independently.

\section{Embryonic development in vitro}

Exposure of females caused a marked increase $(P<0.01)$ in the number of two- and three-cell embryos at the 64-hr period after HCG (Bellvé, 1970). This increase $(P<0.01)$ was apparent in both the female stress and combined stress groups (Table 2, Text-fig. 2). The development of most of the two-cell embryos 


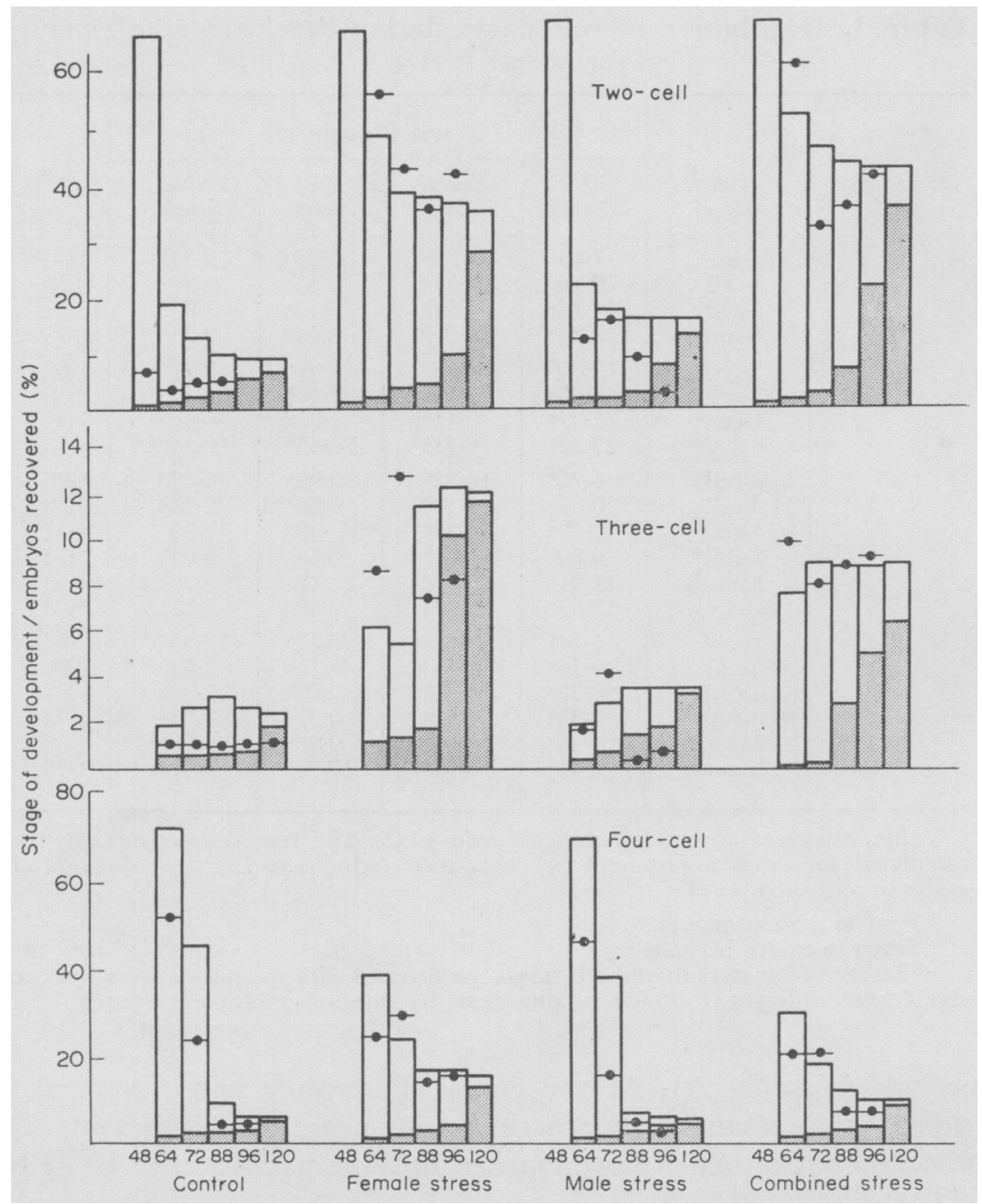

TEXT-FIG. 2. Mean number of two-, three- and four-cell mouse embryos $(\%$ total embryos recovered) for treatment groups and periods of development in vitro (total height of bars) and in vivo ( $)$. Mean numbers of embryos with one or more eosin y-positive blastomeres are given (height of stippled bars) as \% total embryos recovered for periods of development in vitro.

was completely arrested as a result of female exposure. Thus, $75 \%$ and $85 \%$ of the two-cell embryos present in the female stress and combined stress groups, respectively, failed to cleave by $120 \mathrm{hr}$ after HCG. A few two-cell embryos, however, were able to undergo a limited number of cleavage divisions. In addition, there was an increase $(P<0.01)$ in the number of four-cell embryos present at the 88-, 96- and 120-hr periods due to female treatment, indicating that some embryos were arrested at a later stage of development. Morphological examination revealed that the major portion of these embryos had developed to the five-cell stage as a result of only one blastomere having undergone two-cleavage divisions. 


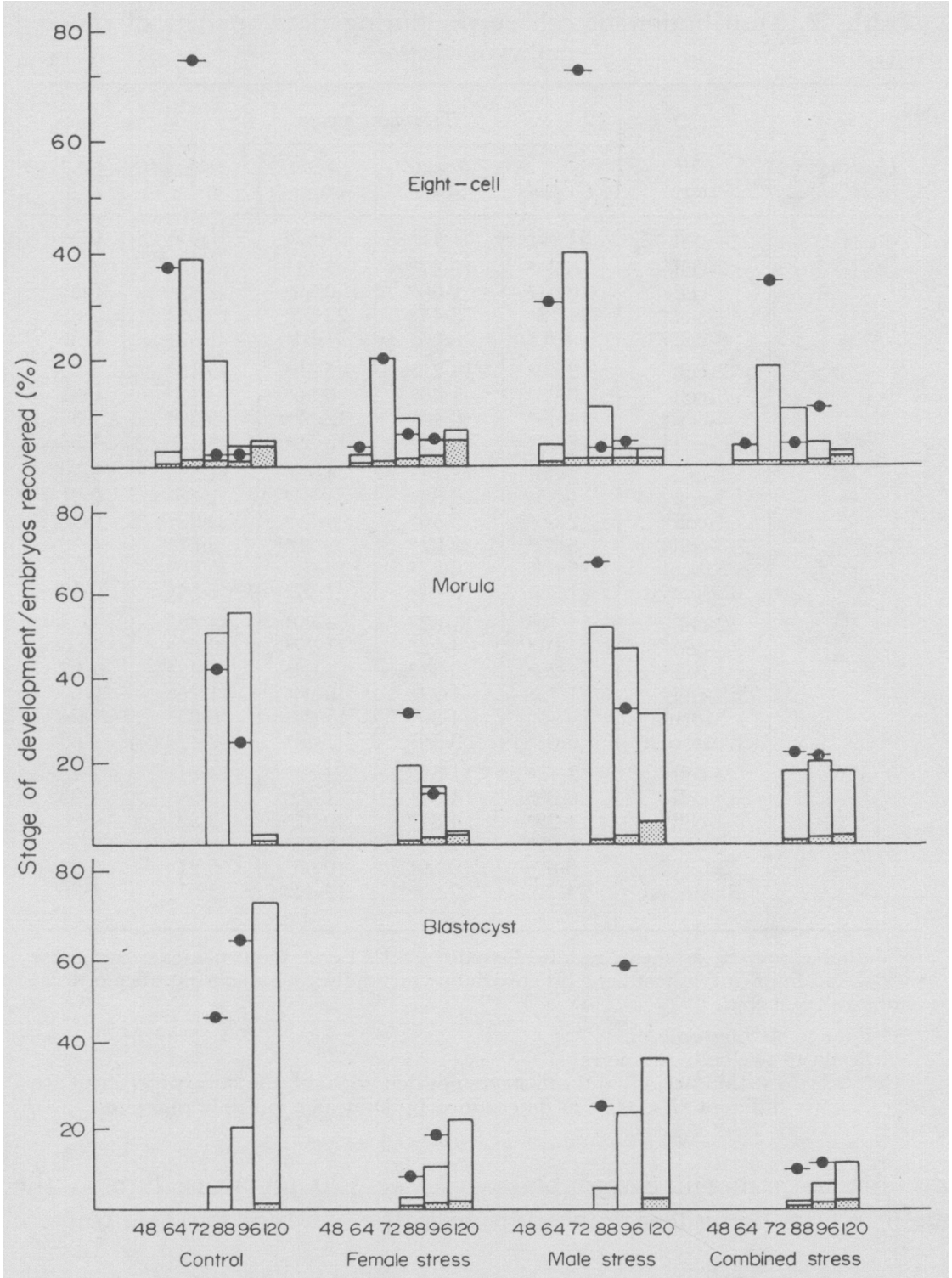

Text-Fig. 3. Mean number of eight-cell mouse embryos, morulae and blastocysts $(\%$ total embryos recovered) for treatment groups and periods of development in vitro (total height of bars) and in vivo (e). Those embryos with one or more eosin y-positive blastomeres are given (height of stippled bars) as \% total embryos recovered for periods of development in vitro.

By contrast, exposure of males resulted in some developmental retardation at the eight-cell stage and a marked accumulation $(P<0.01)$ of morulae at the 120-hr period. Concomitant with these observations, there was a significant decrease $(P<0.01)$ in the number of embryos developing to the blastocyst stage. As with the in-vivo data, significant $(P<0.05)$ male $\times$ female treatment inter- 
Table 2. Distribution of cell stages during development of mouse embryos in vitro

\begin{tabular}{|c|c|c|c|c|c|c|}
\hline \multirow[b]{2}{*}{$\begin{array}{c}\text { Hours after } \\
\text { HCG }\end{array}$} & \multirow[b]{2}{*}{$\begin{array}{l}\text { Cell } \\
\text { stage }\end{array}$} & \multicolumn{4}{|c|}{ Treatment groups } & \multirow[b]{2}{*}{ $\pm S . E$} \\
\hline & & Control & $\begin{array}{c}\text { Female } \\
\text { stress }\end{array}$ & $\begin{array}{l}\text { Male } \\
\text { stress }\end{array}$ & $\begin{array}{c}\text { Combined } \\
\text { stress }\end{array}$ & \\
\hline 48 & 2-cell & $31 \cdot 66^{\mathrm{a}}$ & $31 \cdot 47^{\mathrm{a}}$ & $31 \cdot 62^{a}$ & $31 \cdot 05^{\mathrm{a}}$ & $0 \cdot 34$ \\
\hline 64 & $\begin{array}{l}\text { 2-cell } \\
\text { 3-cell } \\
\text { 4-cell* } \\
\text { 8-cell } \dagger\end{array}$ & $\begin{array}{r}6 \cdot 35^{\mathrm{a}} \\
0.51^{\mathrm{a}} \\
24 \cdot 13^{\mathrm{a}} \\
0 \cdot 70^{\mathrm{a}}\end{array}$ & $\begin{array}{r}15 \cdot 37^{\mathrm{b}} \\
2 \cdot 08^{\mathrm{b}} \\
13 \cdot 44^{\mathrm{b}} \\
0.60^{\mathrm{a}}\end{array}$ & $\begin{array}{r}7 \cdot 11^{\mathbf{a}} \\
0 \cdot 59^{\mathrm{a}} \\
22 \cdot 71^{\mathrm{a}} \\
1.34^{\mathrm{a}}\end{array}$ & $\begin{array}{r}16 \cdot 78^{\mathrm{b}} \\
2 \cdot 82^{\mathrm{b}} \\
10 \cdot 02^{\mathrm{b}} \\
1.56^{\mathrm{a}}\end{array}$ & $\begin{array}{l}1.94 \\
0.37 \\
1.86 \\
0.36\end{array}$ \\
\hline 72 & $\begin{array}{l}\text { 2-cell } \\
\text { 3-cell } \\
\text { 4-cell* } \\
\text { 8-cell } \dagger\end{array}$ & $\begin{array}{r}3 \cdot 58^{\mathrm{a}} \\
0 \cdot 83^{\mathrm{a}} \\
14 \cdot 88^{\mathrm{a}} \\
12 \cdot 54^{\mathrm{a}}\end{array}$ & $\begin{array}{c}14 \cdot 25^{\mathrm{b}} \\
1 \cdot 88^{\mathrm{a}} \\
8 \cdot 46^{\mathrm{b}} \\
6 \cdot 83^{\mathrm{b}}\end{array}$ & $\begin{array}{r}5 \cdot 49^{\mathrm{a}} \\
0 \cdot 96^{\mathrm{a}} \\
12 \cdot 52^{\mathrm{a}} \\
12 \cdot 56^{\mathrm{a}}\end{array}$ & $\begin{array}{c}15 \cdot 18^{\mathrm{b}} \\
3 \cdot 13 \\
6 \cdot 20^{\mathrm{b}} \\
6 \cdot 57^{\mathrm{b}}\end{array}$ & $\begin{array}{l}1.87 \\
0.44 \\
1.39 \\
1.53\end{array}$ \\
\hline 88 & $\begin{array}{c}\text { 2-cell } \\
\text { 3-cell } \\
\text { 4-cell* } \\
\text { 8-cell } \dagger \\
\text { Morula } \\
\text { Blastocyst }\end{array}$ & $\begin{array}{c}2 \cdot 80^{\mathrm{a}} \\
1 \cdot 15^{\mathrm{a}} \\
2 \cdot 66^{\mathrm{ab}} \\
6 \cdot 79^{\mathrm{a}} \\
16 \cdot 83 \\
1 \cdot 46^{\mathrm{a}}\end{array}$ & $\begin{array}{c}12 \cdot 14^{\mathrm{b}} \\
3 \cdot 82^{\mathrm{a}} \\
5 \cdot 50^{\mathrm{b}} \\
2 \cdot 82^{\mathrm{b}} \\
6 \cdot 57^{\mathrm{a}} \\
0 \cdot 64^{\mathrm{a}}\end{array}$ & $\begin{array}{c}4 \cdot 73^{\mathrm{a}} \\
1 \cdot 25^{\mathrm{a}} \\
1 \cdot 57^{\mathrm{a}} \\
3 \cdot 59^{\mathrm{ab}} \\
18 \cdot 61 \\
1 \cdot 57^{\mathrm{a}}\end{array}$ & $\begin{array}{c}14 \cdot 53^{\mathrm{b}} \\
2 \cdot 68^{\mathrm{a}} \\
3.92^{\mathrm{ab}} \\
3 \cdot 51^{\mathrm{ab}} \\
5 \cdot 89^{\mathrm{a}} \\
0.54^{\mathrm{a}}\end{array}$ & $\begin{array}{l}1.79 \\
0.91 \\
0.98 \\
1.18 \\
1.51 \\
0.40\end{array}$ \\
\hline 96 & $\begin{array}{c}\text { 2-cell } \\
\text { 3-cell } \\
\text { 4-cell* } \\
\text { 8-cell } \dagger \\
\text { Morula } \\
\text { Blastocyst }\end{array}$ & $\begin{array}{r}2 \cdot 48^{\mathrm{a}} \\
1 \cdot 01^{\mathrm{a}} \\
1 \cdot 29^{\mathrm{a}} \\
1 \cdot 15^{\mathrm{a}} \\
19 \cdot 10^{\mathrm{a}} \\
6 \cdot 64^{\mathrm{a}}\end{array}$ & $\begin{array}{r}11 \cdot 68^{\mathrm{b}} \\
4 \cdot 12^{\mathrm{b}} \\
5 \cdot 32^{\mathrm{b}} \\
1 \cdot 72^{\mathrm{a}} \\
4 \cdot 80^{\mathrm{b}} \\
3 \cdot 50^{\mathrm{b}}\end{array}$ & $\begin{array}{r}4 \cdot 69^{\mathrm{a}} \\
1 \cdot 27^{\mathrm{a}} \\
1 \cdot 07^{\mathrm{a}} \\
0 \cdot 94^{\mathrm{a}} \\
15 \cdot 99^{\mathrm{a}} \\
7 \cdot 43^{\mathrm{a}}\end{array}$ & $\begin{array}{c}14 \cdot 36^{\mathrm{b}} \\
2 \cdot 80^{\mathrm{a}} \\
3 \cdot 47^{\mathrm{ab}} \\
1 \cdot 25^{\mathrm{a}} \\
6 \cdot 85^{\mathrm{a}} \\
2 \cdot 47^{\mathrm{b}}\end{array}$ & $\begin{array}{l}1.78 \\
1.06 \\
1.02 \\
0.64 \\
1.96 \\
1.83\end{array}$ \\
\hline 120 & $\begin{array}{c}\text { 2-cell } \\
\text { 3-cell } \\
\text { 4-cell* } \\
\text { 8-cell† } \\
\text { Morula } \\
\text { Blastocyst }\end{array}$ & $\begin{array}{c}2 \cdot 47^{\mathrm{a}} \\
0 \cdot 85^{\mathrm{a}} \\
1 \cdot 28^{\mathrm{a}} \\
0 \cdot 99^{\mathrm{a}} \\
0 \cdot 62^{\mathrm{a}} \\
24 \cdot 77\end{array}$ & $\begin{array}{c}11 \cdot 53^{\mathrm{b}} \\
4 \cdot 07^{\mathrm{a}} \\
4 \cdot 87^{\mathrm{b}} \\
2 \cdot 12^{\mathrm{a}} \\
0 \cdot 60^{\mathrm{a}} \\
7 \cdot 33^{\mathrm{ab}}\end{array}$ & $\begin{array}{c}4 \cdot 69^{\mathrm{a}} \\
1 \cdot 09^{\mathrm{a}} \\
0 \cdot 82^{\mathrm{a}} \\
0 \cdot 94^{\mathrm{a}} \\
10 \cdot 66 \\
12 \cdot 44^{\mathrm{a}}\end{array}$ & $\begin{array}{c}14 \cdot 21^{\mathrm{b}} \\
3 \cdot 09^{\mathrm{a}} \\
3 \cdot 33^{\mathrm{ab}} \\
0 \cdot 85^{\mathrm{a}} \\
5 \cdot 91^{\mathrm{a}} \\
3 \cdot 61^{\mathrm{b}}\end{array}$ & $\begin{array}{l}1.78 \\
1.05 \\
0.96 \\
0.55 \\
0.92 \\
1.86\end{array}$ \\
\hline
\end{tabular}

Values expressed as mean number/female \pm S.E. Least squares means are those calculated following adjustment by covariance techniques for mean number of total embryos recovered.

* Four to six blastomeres.

$\uparrow$ Seven to twelve blastomeres.

$a, b, c$ Means within periods and cell stages not denoted with the same superscript are significantly different $(P<0.05)$ as determined by Duncan's multiple range test.

actions, for both morulae and blastocysts at $120 \mathrm{hr}$, were due to the two treatment effects being less than additive in the combined stress group.

$A$ contrast of embryonic development in vivo and in vitro

Culture in vitro markedly retarded embryonic development. Over all treatment combinations, the number of blastocysts at 96 and $120 \mathrm{hr}$ was less $(P<$ $0 \cdot 01$ ) following development in vitro than with development in vivo (Text-fig. 3 ). This retardation during embryonic development in vitro is also indicated by the number of four-and eight-cell embryos at 64 and $72 \mathrm{hr}$, and morulae at 88 and $96 \mathrm{hr}$ after HCG.

There were significant culture $\times$ female treatment interactions in the number of two-cell $(P<0.01)$, three-cell $(P<0.05)$, four-cell $(P<0.05)$ and eight-cell $(P<0.05)$ stages at $64 \mathrm{hr}$ after HCG. In each instance, the interactions were present because the effect of female treatment on developmental retardation 
was less marked in vitro than in vivo. The reverse situation existed in the control and male stress groups.

\section{Incorporation of eosin $y$}

Preliminary analyses within cell stages of data on embryos that incorporated eosin y failed to reveal any differences between treatment combinations that could not be ascribed to differences that existed in the number of embryos available. However, only a limited number of embryos contained blastomeres that were eosin y-positive at 48,64 and $72 \mathrm{hr}$ after HCG following culture in vivo or in vitro (Text-figs 2 and 3 ). At later periods, there was a substantial increase in the number of arrested two- and three-cell embryos that were eosin y-positive. There was also a pronounced increase in the number of blastomeres in each embryo that incorporated the stain. Observations indicated that blastomeres incorporated eosin y approximately $12 \mathrm{hr}$ before the time at which cytoplasmic shrinkage and necrosis became apparent.

Similar trends were observed with four- and eight-cell embryos (Text-figs 2 and 3), but only a limited proportion of morulae and blastocysts showed any indication of an affinity for eosin y. Among the eosin y-positive blastocysts at $120 \mathrm{hr}$ in vitro, particularly those from the female stress and combined stress groups, stained blastomeres were confined to the embryonic disc. The trophoblastic cells were eosin y-negative in these embryos.

\section{Embryonic survival at Day 10 of gestation}

Examination of uteri recovered from females killed at Day 10 of gestation exhibited a marked reduction $(P<0.01)$ in the numbers of implant sites and viable fetuses following either male or female treatment. Treatment means expressed as the percentage mean number of implant sites in the control group (Table 3) show that $45.2,51.9$ and $21.7 \%$ of embryos survived to induce

Table 3. Implant sites, viable fetuses and non-viable mouse embryos at Day 10 of gestation

\begin{tabular}{l|c|c|c|c|c}
\hline & \multicolumn{4}{|c|}{ Treatment groups } & \\
\cline { 2 - 5 } \multicolumn{1}{c|}{ Characteristic } & Control & $\begin{array}{c}\text { Female } \\
\text { stress }\end{array}$ & $\begin{array}{c}\text { Male } \\
\text { stress }\end{array}$ & $\begin{array}{c}\text { Combined } \\
\text { stress }\end{array}$ & \multirow{2}{*}{ \pm S.E. } \\
\hline Implant sites & 23.33 & $10 \cdot 53^{\mathrm{ab}}$ & $12 \cdot 13^{\mathrm{a}}$ & $5 \cdot 13^{\mathrm{b}}$ & $2 \cdot 10$ \\
Viable fetuses & 21.87 & $9 \cdot 00^{\mathrm{a}}$ & $7 \cdot 87^{\mathrm{ab}}$ & $2 \cdot 93^{\mathrm{b}}$ & 1.83 \\
Non-viable embryos & $1.46^{\mathrm{a}}$ & $1 \cdot 53^{\mathrm{a}}$ & $4 \cdot 26^{\mathrm{b}}$ & $2 \cdot 20^{\mathrm{ab}}$ & 0.91 \\
Non-viable embryos* & $0.55^{\mathrm{a}}$ & $1.90^{\mathrm{ab}}$ & $5 \cdot 37^{\mathrm{c}}$ & $3 \cdot 63^{\mathrm{bc}}$ & 0.70 \\
\hline
\end{tabular}

Values expressed as mean number/female \pm S.E.

* Means are those calculated using only females with one or more implant sites and adjusted by covariance for mean number of implant sites.

$\mathbf{a}, \mathbf{b}, \mathbf{c}$ Least squares means not denoted by the same superscript are significantly different $(P<0.05)$ as determined by Duncan's multiple range test.

implant sites in the female stress, male stress, and combined stress groups, respectively. A similar pattern occurred in the data on viable fetuses. Significant $(P<0.05)$ male $\times$ female treatment interactions in the number of viable fetuses occurred as a result of the treatment effects being more than additive, again 
indicating that the treatment effects do not operate with complete independence in the combined stress group.

\section{DISCUSSION}

The distribution of cell stages during development of ICR mouse embryos in vivo is comparable to previous studies on strain 129 (Whitten \& Dagg, 1961) and $+/ t^{12}$ heterozygotes (Smith, 1956). Furthermore, the rate of development during culture in vitro was similar to that reported by Skalko \& Morse (1969) for ICR mouse embryos. The rate of development to the blastocyst stage reported by Bowman \& McLaren (1970) was retarded by the conditions of culture in vitro. This is exemplified in the present data by comparing the number of blastocysts at $96 \mathrm{hr}$ after development (in vivo and in vitro) and is also evident from the greater number of two-, three-, four- and eight-cell embryos present at $64 \mathrm{hr}$. A large number of these embryos was arrested in development. The advantages of culture in vitro for studying experimentally induced embryonic mortality must be weighed against the possible disadvantages of embryonic mortality and developmental retardation occurring as a result of causes other than experimental. In the in-vitro situation, detrimental effects due to natural causes, culture or experimental treatments may easily be confounded.

Complete developmental arrest at the two-cell stage was the principal cause of embryonic mortality following exposure of females. This is in agreement with previous studies in vivo (Elliott, 1968; Bellvé, 1972) and during culture in vitro (Elliott, Burfening \& Ulberg, 1968). Some embryos were arrested, however, at later stages in development, particularly at the three- and four-cell stages. Morphological observations revealed that a major portion of these embryos contained blastomeres of irregular size and in numbers incompatible with synchronized cleavage. It appeared that these embryos arose from a single, or from two successive cleavages, of one blastomere of the original two-cell embryo, thereby forming either three- or five-cell embryos, respectively. Subsequent development led to the formation of trophoblastic vesicles and false blastocysts as observed by Tarkowski \& Wroblewska (1967). This implies that there is a difference in the susceptibility of individual blastomeres to female treatment as well as differences between embryos. The significance of the culture $\times$ female treatment interactions at certain periods after HCG is difficult to ascertain but could be interpreted as indicating either that the environment in vivo was more detrimental to affected embryos, or that the culture medium was providing an environment more favourable to their continued cleavage.

The only effect that could be ascribed to male treatment during development in vivo was a decrease in the number of blastocysts at $96 \mathrm{hr}$ after HCG. During development in vitro, however, there was a minor arrest at the eight-cell stage, a substantial accumulation of morulae and, in consequence, a concomitant decrease in the number of blastocysts at $120 \mathrm{hr}$. Morphologically, embryos at the morula stage appeared normal, with no apparent cytoplasmic shrinkage or pycnosis. The extensive embryonic mortality evident at Day 10 of gestation indicated that a large proportion of the morulae and/or blastocysts from male treatment did not develop into viable fetuses. 
Embryos arrested in development at the two-, three- and four-cell stages after female stress did not incorporate eosin y to any extent until the 96-hr period. Arrested two-cell embryos thus retained cellular integrity for about $48 \mathrm{hr}$. At this time, mechanisms that maintained embryonic integrity gradually failed, eosin y was incorporated and, about $12 \mathrm{hr}$ later, cytoplasmic shrinkage and necrosis became evident. Embryos which accumulated at the morula stage following male stress also continued to exclude eosin y during the remainder of the experimental period. These observations indicate that, while embryos were arrested in development, actual death did not occur until a later time.

\section{ACKNOWLEDGMENTS}

The author is indebted to Dr Eugene J. Eisen, Department of Animal Science, North Carolina State University at Raleigh, for his counsel and advice on statistical procedures. Appreciation is extended to Dr L. C. Ulberg, Mrs G. A. Rowland, Mrs A. Ticehurst, Mr G. Marsh, Jr and Mr T. L. Wagoner of the Reproductive Physiology Research Laboratories at North Carolina State University; and to Miss Marilyn Jacobs of this Laboratory for preparation of the typescript.

\section{REFERENCES}

BeLlvÉ, A. R. (1970) A contrast of normal and abnormal development in the mouse. Ph.D. thesis, North Carolina State University at Raleigh.

Bellve, A. R. (1972) Viability and survival of mouse embryos following parental exposure to high temperature. F. Reprod. Fert. 30, 71.

Bowman, P. \& McLaren, A. (1970) Cleavage rate of mouse embryos in vivo and in vitro. J. Embryol. exp. Morph. 24, 203.

Brinster, R. L. (1969) Mammalian embryo culture. In: The Mammalian Oviduct. Comparative Biology and Methodology, p. 419. Eds. E. S. E. Hafez and R. J. Blandau. University of Chicago Press, Chicago.

Burfening, P. J., Elliott, D. S., Eisen, E. J. \& Ulberg, L. C. (1970) Survival of embryos resulting from spermatozoa produced by mice exposed to elevated ambient temperature. 7. Anim. Sci. 30, 578.

Duncan, D. B. (1955) Multiple range and multiple F tests. Biometrics, 11, 1.

ELLIOTt, D. S. (1968) Developmental alterations in mouse embryos subjected to temperature stress in vivo during the first cell division. Ph.D. thesis, North Carolina State University at Raleigh. University Microfilm, Ann Arbor, Michigan.

Elliott D. S., Burfening, P. J. \& Ulberg, L. C. (1968) Subsequent development during incubation of fertilized mouse ova stressed by high ambient temperatures. J. exp. Zool. 169, 481.

HARVEY, W. R. (1960) Least squares analysis of data with unequal subclass numbers. Tech. Bull. U.S. Dep. Agric. ARS-20-8:1.

Holmberg, B. (1961) On the permeability to lissamine green and other dyes in the course of cell injury and cell death. Expl Cell Res. 22, 406.

Pennycuik, P. R. (1967) A comparison of the effects of a range of high environmental temperatures and of two different periods of acclimatization in the reproductive performance of male and female mice. Aust. 7. exp. Biol. med. Sci. 45, 527.

Skalko, R. G. \& Morse, J. M. D. (1969) The differential response of the early mouse embryo to actinomycin $\mathrm{D}$ in vitro. Teratology, 2, 47.

Sмттн, L. J. (1956) A morphological and histochemical investigation of a pre-implantation lethal $\left(\mathrm{t}^{\mathbf{1 2}}\right)$ in the house mouse. F. exp. Zool. 132, 51.

TARkowsKi, A. K. \& WroblewsKa, J. (1967) Development of blastomeres of mouse eggs isolated at the 4- and 8-cell stage. F. Embryol. exp. Morph. 18, 155.

Whitten, W. K. \& DAGG, C. P. (1961) Influence of spermatozoa on the cleavage rate of mouse eggs. F. exp. Zool. 148, 173. 